\title{
FREIGHT TRANSPORT IN THE CROSS-BORDER AREAS OF THE SILESIAN VOIVODESHIP IN THE CONTEXT OF THE BALTIC-ADRIATIC CORRIDOR
}

\author{
Radosław LUBERA ${ }^{1 *}$, Mateusz ZACZYK ${ }^{2}$ \\ ${ }^{1}$ Silesian University of Technology, Faculty of Organization and Management; radoslaw.lubera@polsl.pl, \\ ORCID: 0000-0002-2919-7009 \\ ${ }^{2}$ Silesian University of Technology, Faculty of Organization and Management; mateusz.zaczyk@polsl.pl, \\ ORCID: 0000-0002-3206-4784 \\ * Correspondence author
}

Purpose: The purpose of the article is to analyze the operation of freight transport in the crossborder area of the Silesia Voivodeship in the context of the existence of the Baltic-Adriatic transport corridor. An additional objective is to indicate the priority areas of the corridor under consideration, as well as key actions to improve the functioning of freight transport in the area under consideration.

Design/methodology/approach: The article was mainly based on a thorough analysis of quantitative and qualitative data contained in documents made available by the European Union institutions and reports.

Findings: Identification of the most significant steps the authors consider to be taken to improve freight transport in the analyzed region, which is considered by the authors to be priority actions.

Originality/value: The originality of the article consists in carrying out a qualitative assessment of the condition of the freight transport infrastructure in the context of the functioning of the selected transport corridor and identifying bottlenecks in its functioning.

Keywords: transport corridor, bottleneck, infrastructure, Silesian Voivodeship.

Category of the paper: Research paper.

\section{Introduction}

The idea of creating a coherent, compact and efficient transport corridor was born to maintain a well-functioning freight economy in Europe. Proper adjustment of point and line infrastructure on transport routes along with proper understanding of the issues of material flow management within the supply chain and the security context within the supply chain requires knowledge of selected concepts, which indicates flows as the main azimuth of target orientation 
of businesses, which form links in supply chains. This concept is the starting point for reflection on the legitimacy of creating advanced international communication routes across the European continent. The purpose of the article is to analyze the operation of freight transport in the crossborder area of the Silesia Voivodeship in the context of the existence of the Baltic-Adriatic transport corridor. An additional objective is to indicate the priority areas of the corridor under consideration, as well as key actions to improve the functioning of freight transport in the area under consideration.

\section{Baltic-Adriatic Corridor as part of the trans-European transport network}

The course and infrastructure of the Baltic-Adriatic Corridor were strictly defined in the Regulations of the European Parliament and of the Council No. 1315/2013 and 1316/2013 concerning the development of the trans-European transport network. The spatial planning of the corridor was to stretch between the Baltic Sea, exactly its southern coast and the Adriatic Sea, more specifically its Italian and Slovenian parts. In addition to the previously mentioned republics, the corridor runs through Austria, Czechia, Slovakia and Poland (the countries are listed from south to north). The main reason for the creation of the corridor was the connection of Polish ports in Gdynia, Gdańsk, Szczecin and Świnoujście with ports in the Adriatic Sea basin, including the Sistema Portuale del Mare Adriatico Orientale - Porto di Trieste, Sistema Portuale del Mare Adriatico Settentrionale - Porti di Venezia e Chioggia, Sistema Portuale del Mare Adriatico Centro-Settentrionale - Porto di Ravenna and the Port of Koper (Rozporządzenie Parlamentu Europejskiego...).

The Baltic-Adriatic Corridor is a route with an average length of 1,800 km (the exact distance varies depending on the choice of individual urban nodes), which allows the creation of more viable transport routes between the Baltic and Adriatic Sea basins. The route examples are dependent mostly on the choice of starting and ending port, for example, the north-south direction can be taken from the Szczecin or Świnoujście port and then travel through Poznań and Wrocław, or from Gdynia or Gdańsk to Katowice or from Warsaw to Łódź. The corridor can connect Polish core network urban and logistic nodes with nodes located in Czechia, Slovakia and Austria, for example in Vienna via Bratislava or Ostrava. The network offers opportunities for intermodal transport, e.g., in Austria, where road and rail corridor connections run towards the Adriatic Sea ports: Koper, Trieste, Venice and Ravenna, through Ljubljana in Slovenia or through Udine, as well as running through Venice and Bologna in Italy (Bodewig, 2016, p. 7). 




Figure 1. The course of the Baltic-Adriatic corridor. Source: The Baltic-Adriatic corridor study consortium.

In the area of corridor there are a total of 13 urban nodes and airports, 10 ports and nearly 24 active rail and road terminals (Bodewig, 2016, p. 7). It is built on the basis of the BalticAdriatic transport axis, which is dominated by rail and road routes. One of the main drawbacks of the corridor is that it is one of the few corridors that does not include inland waterways, even if it connects to the core network of the TEN-T inland waterways on different sections. However, this situation may be changed due to the planned expansion of the inland waterway transport network in Moravia. On the other hand, one of the greatest advantages of the corridor is the large number of other corridors that cross it transversely. From north to south, in order, these are the following (Lijewski, 2003):

- North Sea-Baltic Corridor, intersection in Poznań and Warsaw,

- Rhine-Danube corridor, intersection near Ostrava, Žilina, Bratislava and Vienna,

- East Mediterranean corridor, intersection near Brno, Bratislava and Vienna,

- Mediterranean corridor, covering the routes between Ravenna and Ljubljana,

- Scandinavian-Mediterranean corridor, covering the routes between Ravenna and Bologna.

\section{Main objectives for the development of the Baltic-Adriatic Corridor}

The underlying principles, objectives and priorities for the development of all corridors are set out in Articles 4 and 10 of the TEN-T Regulation (EU) No. 1315/2013. These articles indicate the importance of the following objectives for the proper planning and organisation of the corridors: 
- coherence of the corridors, understood as:

$\circ$ ensuring accessibility and balancing of infrastructure differences between countries along the route of a given corridor,

- maintaining the development of long-distance, regional and local connections,

- efficiency of the corridors, understood as:

○ removal of bottlenecks,

- complementing the existing services if necessary,

- minimising bureaucracy in cross-border areas,

$\circ$ the integration of different modes of transport,

$\circ$ increasing the throughput,

- sustainable development, understood as:

$\circ$ increasing safety by improving the quality of the infrastructure along the entire corridor,

○ maintaining resilience to random events, i.e., natural disasters, environmental impacts and climate change,

- implementation of telematics solutions,

○ promotion of technological innovations,

0 balancing differences in the quality of services.

Moreover, the document indicates that the quality criteria for the level of transport infrastructure along the entire corridor route must be met by 2030. As part of the verification of the discrepancy between the qualitative baseline and the expected level, a qualitative inspection was carried out in 2015-2017 using performance indicators (KPIs) in the nine largest European corridors, including the Baltic-Adriatic corridor. The analysis was carried out for the supply side of the KPI value of the Baltic-Adriatic corridor. The research was conducted for five different modes of transport: rail, road, sea, inland waterway, air and rail-road terminals. Criteria taken into account depending on the mode of transport were (www.tentdays.eu/...):

- rail: electrification, track gauge $(1,435 \mathrm{~mm})$, ERTMS implementation, line speed $(\geq 100 \mathrm{~km} / \mathrm{h})$, axle load $(\geq 22.5 \mathrm{t})$, train length $(740 \mathrm{~m})$,

- road: express roads/motorways, availability of clean alternative fuels,

- air: airport rail link, open access to at least one terminal, availability of clean alternative fuels,

- sea: port rail link, connection to inland waterways of class IV, availability of clean alternative fuels, open access to at least one terminal, reception facilities for shipgenerated waste,

- inland: connection of the port to inland waterways of class IV, rail link, open access to at least one terminal, availability of clean alternative fuels',

- road-rail terminals: intermodal transhipment possibility, access for train sets $740 \mathrm{~m}$ long, access for electric trains, open access to at least one terminal. 


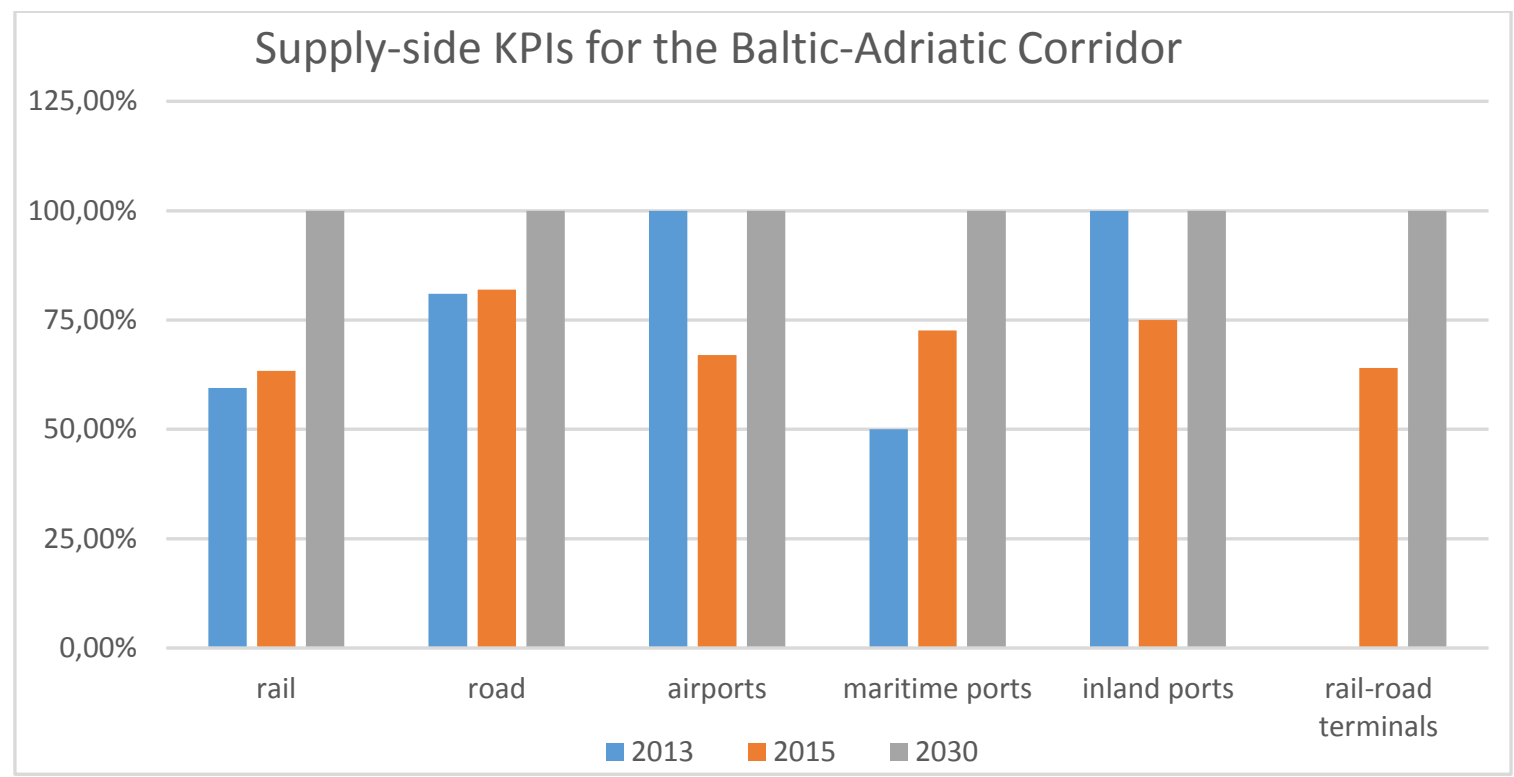

Figure 2. Supply-side KPIs for the Baltic-Adriatic Corridor. Source: https://www.tentdays.eu/ 2018/assets/doc/25_04_URSKAS/25_04_URSKA_4/16h00_18h00/Bodewing\%20\&\%20Brocks.pdf, 4.04.2019.

The research was carried out in 2013 and 2015 and the indicator was used to assess the current quality status of all the criteria, then it was compared with the expected (100\%) level in 2013. In most cases there is a growing tendency that brings the corridor closer to the target level. In the case of airports and inland ports, the sudden drop is due to the necessity to provide the industry with access to clean alternative fuels in 2015. In 2013 there was not such a necessity. Hence, a 100\% KPI level. More detailed research can be found in the next part of the article (www.tentdays.eu/...).

\section{Identification of bottlenecks in freight transport in the cross-border area of the Silesian Voivodeship}

The characteristics of the Baltic-Adriatic transport corridor considered in the context of the compliance of its elements with the requirements of the Trans-European Transport Network implies the need to identify bottlenecks within its framework, with particular emphasis on the elements located in the cross-border area of the Silesian Voivodeship. The identified weaknesses of the existing infrastructure are characterised by numerous throughput limitations, and on many occasions we are witness to sectional deficiencies of the railway and road infrastructure (Macharis, Pekin, 2009). 


\section{Rail transport}

A number of bottlenecks also include areas where operational and administrative barriers are identified, as well as some problematic urban nodes. The identification of bottlenecks is a suggestion of places to undertake future key actions aimed at improving the functioning of the Baltic-Adriatic Corridor, which in turn should translate into the implementation of the strategic objectives of the Trans-European Transport Network. Analysing the documentation of "The Baltic-Adriatic Corridor Study Consortium" (Bodewig, 2016, p. 40), in the cross-border area of the Silesian Voivodeship, covering the areas of Poland, Czechia and Slovakia, the sections of Opole-Ostrava, Katowice-Ostrava, Katowice-Žilina and Katowice-Ostrava are among the most significant sections of the railway infrastructure requiring improved functioning (Figure 2).

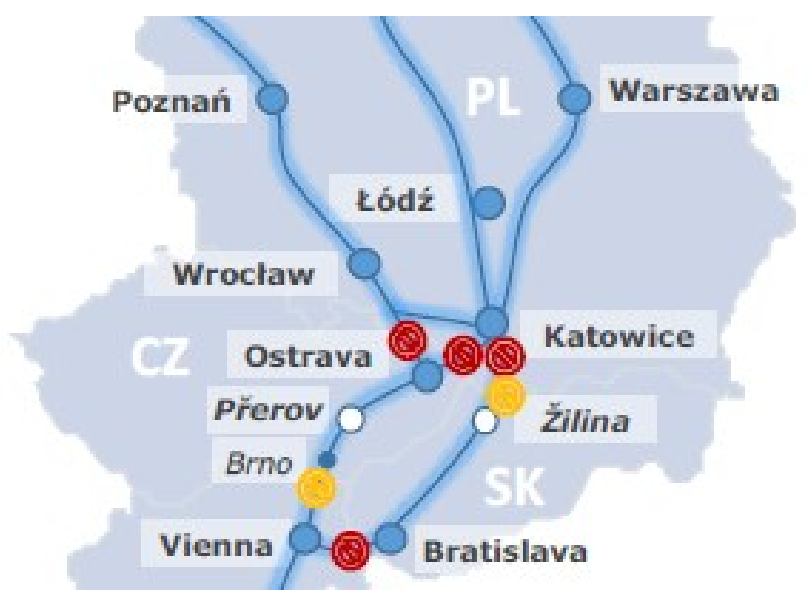

Figure 3. Location of cross-border transport bottlenecks in the Silesian Voivodeship. Source: https://ec.europa.eu/transport/themes/infrastructure/baltic-adriatic_en, 4.04.2019.

As far as the areas located entirely within the territory of the Republic of Poland are concerned, the section Chorzów Batory-Gliwice Łabędy (the part of E65 and E30 lines) and the sections located between Wrocław and Katowice are worth noticing. The above-mentioned works aimed at improving freight transport are planned for the period until the end of 2023. However, they will not eliminate all the problems occurring within the railway connections network in the cross-border area of the Silesian Voivodeship. In order to achieve compliance with the standards of the Trans-European Transport Network, it will be necessary to undertake works on the freight sections Opole Groszowice-Rudziniec Gliwicki and short sections located in Kędzierzyn Koźle. Limitations (train length requirements) are currently also present in the Tarnowskie Góry - Katowice and Opole-Gliwice sections (Bodewig, 2016, pp. 40-44).

Czechia, on the other hand, faces capacity and speed limitations (compared to the standards of the Trans-European Transport Network) in the areas of Brno and Ostrava. The modernisation of the station in Prerov is also ongoing, along with the construction of its bypass. It is estimated that in 2030 the TEN-T requirements will not be met in the sections (freight and passenger) of Ostrava-Prerov and Prerov-Breclav) In Slovakia, critical bottlenecks have been identified at the most important railway junctions - Žilina and Bratislava (Adelsberger, Eicher, 2018). The restrictions concern mostly the maximum speed of the trains (reaching only $60 \mathrm{~km} / \mathrm{h}$ ). 
In addition, Slovakia identifies a number of problems on the Bratislava-Vienna route, although these issues are not dealt with in this article.

\section{Road transport and urban nodes}

When analysing infrastructural problems related to road freight transport in the BalticAdriatic Corridor, it is necessary to point out the impediments related to modernisation of (Adelsberger, Eicher, 2018, p. 43-46):

- the A1, S3, S7 and A4 roads in the Republic of Poland,

- the D1 motorway in the section Rikovice-Prerov-Lipnik in Czechia,

- the D3 motorway in Žilina, D1 motorway in the Tranava-Bratislava section in Slovakia.

The issues relating to road transport infrastructure are much less common than those relating to rail transport. Bottlenecks in the area of urban railway infrastructure nodes often lie in the failure to meet requirements in terms of train length, maximum speed, axle load and the European Rail Traffic Management System (ERTMS). For the area covered by this article, the most significant issues have been identified in Katowice, Wrocław, Ostrava and Bratislava nodes (Wiśniewski, 2015, pp. 83-92).

\section{Actions taken to improve the flow of goods within the Baltic-Adriatic Corridor}

In terms of compliance with the Trans-European Transport Network, the measures taken in 2013-2017 to improve freight transport throughout the Baltic-Adriatic Corridor have contributed more to meeting most of the technical requirements. Table 1 illustrates the compliance of the Baltic-Adriatic Corridor with the selected technical standards of the TEN-T network in 2013 and 2017.

Table 1.

Compliance of the Baltic-Adriatic Corridor with TEN-T standards

\begin{tabular}{|l|l|l|}
\hline Standard/year & $\mathbf{2 0 1 3}$ & $\mathbf{2 0 1 7}$ \\
\hline Electrification level & $99 \%$ & $99 \%$ \\
\hline Track gauge $1,435 \mathrm{~mm}$ & $100 \%$ & $100 \%$ \\
\hline ERTMS implementation & $0 \%$ & $17 \%$ \\
\hline Line max speed $(\geq 100 \mathrm{~km} / \mathrm{h})$ & $69 \%$ & $72 \%$ \\
\hline Axle load $(\geq 22,5 \mathrm{t})$ & $89 \%$ & $93 \%$ \\
\hline Train length $(740 \mathrm{~m})$ & $16 \%$ & $29 \%$ \\
\hline
\end{tabular}

Source: https://www.tentdays.eu/2018/assets/doc/25_04_URSKAS/25_04_URSKA_4/16h00_18h00/ Bodewing\%20\&\%20Brocks.pdf, 4.04.2019. 
Table 1 shows a substantial increase in most technical standards, although some of them are further measures to further increase the presented indicators. The latest, Third Work Plan of the European Coordinator for the Baltic-Adriatic Corridor, indicates a number of planned projects aimed at further development of the Baltic-Adriatic Corridor, which includes the cross-border area of the Silesian Voivodeship. The analysed document therefore identified 551 projects related to the development of the corridor which are already underway or planned to be implemented. Their total budget amounts to $€ 76.9$ billion. Most ongoing and planned projects (337) are expected to be completed by 2020, 189 are planned to be completed after 2020, and for 25 projects, implementation dates are either not available or not currently defined. The priority work plans include 186 investments, of which 12 have not yet been scheduled for completion, 82 should be implemented by 2020. In total, priority actions will amount to $€ 35.2$ billion, representing more than $45 \%$ of the total number of projects (Bodewig, 2018, pp. 28-49).

\section{Modernisation of railway lines and implementation of ERTMS}

The list of projects aiming to develop the railway infrastructure of the Baltic-Adriatic Corridor includes 134 projects with a total value of $€ 34.7$ billion. Modernisation work to achieve the TEN-T network standards is underway and is planned for cross-border sections between Poland and Czechia and Slovakia, Slovakia and Austria, Austria and Slovenia and Slovenia and Italy, as well as for national areas in Poland and Slovenia. In Czechia, Slovakia, Austria and Italy, lines and improvements at junctions and nodes need to be upgraded to increase throughput capacity, including studies and projects on the development of high-speed lines. Initiatives are also planned to improve rail infrastructure and stations by achieving technical standards for interoperability. Thirty-one rail transport initiatives are finally classified as projects to implement ERTMS (approximately $€ 1.9$ billion of investment) (Bassetti, Carteny, 2012, pp. 61-68). Eight of them concern the installation of ERTMS technology on rolling stock in a corridor and other EU Member States, and initiatives to support the deployment of ERTMS technology at multi-country and multi-corridor levels.

In addition to the above-mentioned projects for the development of railway infrastructure and the deployment of ERTMS, 14 projects for the development of railway terminals are currently in progress (total value of $€ 569$ million). They are related mainly to the cross-border area of the Silesian Voivodeship, in the area of development and expansion of multimodal transport infrastructure in cities such as Wrocław (Kąty Wrocławskie), Ostrava, Paskov and Prerov (Bodewig, 2018, pp. 40-49). Initiatives regarding ICT and innovation in general are also ongoing and planned to facilitate intermodality and support the smooth flow of information along the Baltic-Adriatic Corridor. 


\section{Modernisation of road transport infrastructure}

With respect to the modernisation of road transport infrastructure in the Baltic-Adriatic Corridor, 102 projects worth a total of $€ 15.9$ billion are in progress and in the planning phase. Works to modernise the corridor network to reach compliance are planned to be carried out on cross-border sections between Poland and Slovakia, Czechia and Austria, Italy and Slovenia, as well as on national roads in Poland, Czechia and Slovakia. Moreover, studies and works are being carried out on the implementation of Intelligent Transport Systems solutions to improve traffic management and flow orientation, as well as to accelerate the development and accessibility of alternative clean fuels in the Baltic-Adriatic corridor network.

\section{Modernisation of urban nodes}

Within the TEN-T policy framework, urban nodes play an essential role in the development and operation of the core network as a multimodal and interoperable infrastructure for both passenger and freight traffic. The urban nodes along the corridor are linked by network links. They also connect transport modes, increasing multimodality. Finally, they combine long-distance (international) traffic with regional and local transport (passenger and freight). In this respect, the following types of action have been considered in order to identify the appropriate investments to ensure the development of the corridor as an interoperable infrastructure, which can have an impact on both urban areas and major urban nodes (Bodewig, 2018, pp. 31-33):

- Projects with the aim of improving the standards of connections of railway corridors and road networks in urban areas, including stations, sidings, etc.

- Activities to improve rail and road connections directly linking the Baltic-Adriatic corridor with key transport nodes in urban areas.

- Initiatives to improve interconnection between major transport nodes and between modes of transport at major urban nodes, i.e., projects involving regional and suburban railways, underground or tram lines which directly connect to one or more major transport nodes in a central urban area where the services are operated towards other major urban nodes of the core network.

- Initiatives to promote the interconnection of different modes of transport and sustainable transport solutions for both passengers and freight, including ITS, clean fuels, implemented in major urban areas or on a territorial scale encompassing at least one major urban area.

- Other soft or administrative measures to promote integrated transport and mobility in central urban areas towards mobility solutions as a service. 
- Infrastructure solutions to minimise the negative effects of long-distance traffic along a corridor crossing urban areas, including rail and road corridors, regardless of their classification as primary or comprehensive, provided that they are implemented to alleviate the environmental impact of the existing sections of the corridor.

As indicated above, 68 projects with a total value of $€ 9.3$ billion have been identified in the main nodes of the Baltic-Adriatic corridor. These include (Bodewig, 2018, p. 33):

- Activities aimed at improving standards and increasing the throughput capacity of sections of railway corridors in the following main urban nodes: Gdańsk, Warsaw, Łódź, Katowice, Szczecin, Poznań, Wrocław (Poland), Ostrava (Czechia), Bratislava (Slovakia), Vienna (Austria) and Ljubljana (Slovenia).

- Investments to enhance throughput, improve safety and reduce congestion of corridor road infrastructure at major nodes, through the development of corridor bypasses or the modernisation of the corridor and node sections. Projects are located, for example, in Gdańsk, Warsaw, Łódź, Szczecin, Poznań (Poland), Ostrava (Czechia), Bratislava (Slovakia), Vienna (Austria), Bologna (Italy) and Ljubljana (Slovenia).

- Projects to improve multimodal interconnection infrastructure to support the transition from road to rail, also focusing on the development of urban transit infrastructure and interchanges as ITS and ICT solutions for passenger and freight transport (Gdańsk, Szczecin, Łódź, Bratislava, Bologna).

\section{Future priority activities in the cross-border areas of the Baltic-Adriatic Corridor}

Each corridor can only be very effective if its main road and rail bottlenecks in cross-border areas are removed. It is only by investing in cross-border sections that the development of international connections in the countries covered by the corridor can be sustained. At this point, the European added value of joint investments and activities is most evident. The analysis of the Baltic-Adriatic Corridor confirmed that six railway and two road cross-border sections have significant bottlenecks in terms of electrification compliance, axle load, speed and train length. These are the following cross-border railway sections to be addressed as a matter of priority (Stajniak, 2008):

- Opole (Poland) - Ostrava (Czechia), with particular emphasis on the Chałupki (Poland) - Bohumín (Czechia) section;

- Katowice (Poland) - Ostrava (Czechia), with particular emphasis on the Zebrzydowice (Poland) - Petrovice near Karviná (Czechia) section;

- Bratislava (Slovakia) - Vienna (Austria), with particular emphasis on the Devínska Nová Ves (Slovakia) - Marchegg (Austria) section;

- Katowice (Poland) - Žilina (Slovakia), with particular emphasis on the Zwardoń (Poland) - Skalité (Slovakia) section; 
- Graz (Austria) - Maribor (Slovenia), with particular emphasis on the Spielfeld-Straß (Austria) - Šentilj (Slovenia) section;

- Trieste (Italy) - Divača (Slovenia), with particular emphasis on the Villa Opicina (Italy) - Sežana (Slovenia) section.

Moreover, the following cross-border road sections have been identified as critical for compliance as they are neither motorways nor express roads:

- Katowice (Poland) - Žilina (Slovakia), with particular emphasis on the Zwardoń (Poland) - Skalité (Slovakia) section;

- Brno (Czechia) - Vienna (Austria), with particular emphasis on the Mikulov (Czechia) - Mistelbach (Austria) section.

Among the six above-mentioned critical cross-border railway sections, the KatowiceOstrava-Žilina between Poland, Czechia and Slovakia cross-border section is of particular importance because of its position in the relevant economic and industrial area of the corridor with a continuous volume of freight traffic on the lines between Poland and Czechia. The analysis shows that the development of cross-border sections Katowice - Ostrava and Katowice - Žilina is at risk of limited availability of funds on the Polish side. It also makes it more challenging to define implementation deadlines for some of the projects which have been identified in order to fully modernise these lines (Stajniak, 2008). These investments are included in the reserve list of the National Railway Programme for the period up to 2023 and the Polish authorities maintain that these investments will be completed by 2030. However, the fact that project deadlines are not currently defined is a significant uncertainty. On the Katowice - Žilina section, the speed standard on the Zwardon - Skalite cross-border section will not be reached on the Slovakian side either. It was noted that it is located in a hillside area and the development of lines to meet the required standards would result in high construction costs. Nevertheless, solutions should be sought for cross-border corridor sections in order to comply with Article 39 of Regulation (EU) No. 1315/2013.

\section{Summary}

The purpose of this article was to present basic information regarding the necessity of shaping transport corridors between key regions of the European Union, with particular emphasis on the Baltic-Adriatic Corridor. The article describes the current condition of the road and railway infrastructure included in the corridor under consideration, as well as suggests key locations, nodes and sections requiring further investment expenditures. In the first part of the article, the authors presented a number of objectives for the development of transport corridors as elements of the Trans-European Transport Network TEN-T, and then characterised the activities undertaken in the cross-border area of the Silesian Voivodeship and the areas directly 
adjacent to it. The review of the bottlenecks for the efficient implementation of freight transport in the cross-border area of the Silesian Voivodeship is the result of the analysis of the documentation of the authorities of the Silesian Voivodeship and the reports of the European Union institutions. The authors also identified the most significant steps they consider to be taken to improve freight transport in the region, which they consider to be priority actions.

\section{References}

1. Adelsberger, H., Eicher, H. (2018). The Koralm-Line as a Part of Wider European Railway Connections - Integrated in the Baltic-Adriatic-Axis. Geomechanics and Tunnelling, 1, 4.

2. Bassetti, C., Carteny, A. (2012). European Macro-Regional Strategies and Approaches: Baltic Sea and Danube Experiences and the New Perspective for Adriatic-Ionian Cooperation. Mediterranean Journal of Social Sciences, 3(8).

3. Bodewig, K. (2016). Korytarz Baltyk-Adriatyk. Drugi plan pracy Koordynatora Europejskiego. Bruksela.

4. https://www.tentdays.eu/2018/assets/doc/25_04_URSKAS/25_04_URSKA_4/16h00_18h 00/Bodewing\%20\&\%20Brocks.pdf, 4.04.2019.

5. Lijewski, T. (2003). Szlaki tranzytowe przez Polskę (Transit Trails through Poland). In: A. Stasiak (ed.), Book Devoted to the Memory of Professor Marcin Maria Rościszewski, Geopolitical Studies, 10. Warszawa: IGiPZ PAN.

6. Macharis, C., Pekin, E. (2009). Assessing policy measures for the stimulation of intermodal transport: a GIS-based policy analysis. Journal of Transport Geography, 17.

7. Rozporządzenie Parlamentu Europejskiego i Rady nr 1315/2013 z dnia 11 grudnia 2013 r. w sprawie unijnych wytycznych dotyczących rozwoju transeuropejskiej sieci transportowej.

8. Stajniak, M. (2008). Technically-infrastructural conditionings of the realization of intermodal transport connecting the baltic sea with the adriatic sea. $\operatorname{LogForum}, 4,1,3$. Wyższa Szkoła Logistyki.

9. Wiśniewski, S. (2015). The Baltic - Adriatic Transport Corridors - Natural Environment of Logistics Infrastructure Development on the Polish Baltic Sea Coast. Logistics and Transport, 25, 1 . 